\title{
Hypoxia in the newborn infant
}

\author{
E. O. R. REYNOLDS
}

From the Department of Paediatrics, University College Hospital and Medical School, London

Disorders of breathing are the commonest causes of hypoxia and death in newborn infants (Chamberlain et al, 1975). The aim of this article is to describe the disorders in which serious hypoxia is most often encountered, the ways in which it can be prevented or treated, and some of the consequences of hypoxia.

\section{Normal cardio-pulmonary adaptation at birth}

Many disorders of breathing in the newborn period arise because of failure of normal cardio-pulmonary adaptation. In order to understand the pathogenesis of these disorders it is necessary first to summarize the changes that normally take place in the lungs and circulation at birth.

In fetal life the respiratory centre is not, as was once thought, inactive. Breathing movements in utero, first suspected by Ahlfeld (1888), have been clearly demonstrated in the fetal lamb and subsequently in the human fetus (Boddy and Dawes, 1975). At birth, the lungs replace the placenta as the organ of gas exchange and the activity of the respiratory centre becomes closely adjusted to the metabolic needs of the body. The mechanisms responsible have not been fully worked out but they probably depend on the interplay of a number of different stimuli which regularize and control respiratory neuronal discharge. For example, chilling of the skin at birth and stimulation of receptors near the larynx when liquid is cleared from the airway have both been shown to augment breathing (Johnson et al, 1973; Boddy and Dawes, 1975). Carotid chemoreceptor sensitivity to hypoxia increases greatly and there is some evidence for increased central chemoreceptor sensitivity as well (Purves and Biscoe, 1966).

The fetal lung contains about $30 \mathrm{ml} / \mathrm{kg}$ of body weight of liquid. This liquid is a secretion of lung tissue containing very little protein $(25 \mathrm{mg} / \mathrm{dl})$ and its composition differs both from that of an ultrafiltrate of plasma and from amniotic fluid (Adamson et al, 1969; Olver et al, 1973). At birth the infant makes forceful inspiratory efforts, sometimes -60 $\mathrm{cmH}_{2} \mathrm{O}$ (Karlberg et al, 1962), in order to overcome the resistance to the inspiration of air into the liquid- filled lung. The inspiratory efforts not only suck air into the alveoli, they also stretch the alveolare epithelium, which normally has an equivalent pores radius of only $0.5 \mathrm{~nm}$, and is therefore extremely impermeable to solutes (Normand et al, 1971). Thes pores are stretched to about $3.5 \mathrm{~nm}$ in radius (Egan et $a l, 1975)$ and the fetal alveolar liquid passeș through them, down a protein osmotic pressur gradient, into the interstitial tissue of the lung. Fronf there it is absorbed, largely via lymphatics (Humphreys et al, 1967), into the circulation $\vec{c}_{\vec{C}}$ Subsequently the pores in the alveolar epitheliun? contract back towards their fetal size. The secretione of lung liquid stops at birth for reasons that are not understood.

Once breaths of air have been taken, refex mechanisms come into play which are responsitie for rearranging the circulation from the fetal to adult type. In fetal life, the pulmonary arterioles are constricted and only 10 per cent of the cardiac out put perfuses the lungs, the remainder shunting fron the right to the left side of the circulation throug? the foramen ovale and ductus arteriosus (Dawes? 1968). When air enters the lung the partial pressure of oxygen $\left(\mathrm{PO}_{2}\right)$ rises sharply from the normal fetat level of about $25 \mathrm{mmHg}$ to above $60 \mathrm{mmHg}$. This increase in $\mathrm{PO}_{2}$ provides the major stimulus to the large pulmonary arteriolar vasodilatation thas occurs at birth (Cook et al, 1963). Another important. factor promoting vasodilatation is the developmen of surface-tension forces in the alveoli which exers radial traction on blood vessels (Cassin et al, 1964) As a result of pulmonary vasodilatation blood flow through the lungs increases and pressure in the le atrium rises. At the same time, right atrial pressunes falls slightly, mainly because of cessation of the umbilical circulation. The foramen ovale closes when left atrial pressure rises above right atriab pressure. The ductus arteriosus constricts in response to increasing $\mathrm{PO}_{2}$ once breathing has started (Kovalčík, 1963). When the foramen ovale and ductus arteriosus have both closed the whole of the cardiac output must pass through the lungs and fulp oxygenation of the blood can occur.

For several days, sometimes weeks, after birth the 
newborn infant remains extremely vulnerable to reopening of the fetal right-to-left shunts. If, due to a pulmonary illness, atelectasis is present and the $\mathrm{PO}_{2}$ of lung tissue falls, pulmonary vasoconstriction will inevitably follow, and the foramen ovale and ductus arteriosus are likely to reopen. Low $\mathrm{pH}$, common in respiratory illnesses, makes pulmonary vasoconstriction worse (Rudolph and Yuan, 1966). The consequences for the infant may be very serious, since venous blood bypasses the lungs and is directed into the aorta. Reopening of fetal right-to-left shunts is probably the single most important cause of life-threatening hypoxia in the newborn period. Once anatomical closure of these structures has taken place, usually by about two weeks of age, severe hypoxia in association with respiratory illnesses becomes very much less likely.

\section{Failure of normal cardio-pulmonary adaptation at} birth

\section{APNOEA AT BIRTH}

By far the commonest causes of failure to breathe at birth are intrapartum asphyxia and excessive maternal analgesia with opiates. Fetal asphyxia evokes gasping but if the asphyxia is more prolonged the central nervous system, including the respiratory centre, becomes depressed and the infant does not respond to the normal stimuli that augment breathing after birth. Opiates have a direct inhibitory influence on the respiratory centre.

The only sure way to resuscitate an infant who shows no sign of breathing is by endotracheal intubation and positive pressure inflation of the lungs. Because the lungs are filled with liquid a high pressure, $25-30 \mathrm{cmH}_{2} \mathrm{O}$, is needed for the first inflation. This pressure must be applied for about five seconds so that the whole lung becomes evenly inflated. Once the fetal lung liquid has been displaced from the alveoli the lungs can be inflated at lower pressures, about $10-15 \mathrm{cmH}_{2} \mathrm{O}$. Inflation of the lungs with a face mask or mouth-to-mouth breathing is not so effective as intubation because the necessary transpulmonary pressure is more difficult to achieve and also because gastric distension occurs. Alkali therapy is much less commonly used during resuscitation than in the past. Once an infant is properly oxygenated any metabolic acidosis due to anaerobic glycolysis will usually rapidly resolve, and there are possible dangers associated with the overenthusiastic use of hypertonic bicarbonate solution. For example, it might overload the circulation and increase the risk of cerebral haemorrhage (Simmons et al, 1974). Nevertheless there is still a place for the cautious intravenous infusion of alkali if an infant remains cyanosed and slow to breathe following severe intrapartum asphyxia and in spite of adequate inflation of the lungs with oxygen. Such an infant may also benefit from external cardiac massage.

Infants born apnoeic but with good tone and a normal heart rate can often be encouraged to breathe by peripheral stimulation, and intubation is usually not needed. Warmth must always be provided during resuscitation, to minimize oxygen consumption and prevent hypothermia. If the mother has had excessive opiate analgesia and the infant does not breathe adequately, naloxone should be given intravenously.

\section{TRANSIENT TACHYPNOEA OF THE NEWBORN} (WET LUNG)

Some infants who remain short of breath for a few hours, or occasionally a day or two, after birth have chest radiographs showing oedema-like changes, with abnormal linear shadows fanning from the hila (Avery et al, 1966). The only adequate explanation for this condition is that it is due to delayed removal of fetal lung liquid. Possibly the affected infants have excessive amounts of the liquid present in their lungs at birth or, if preterm, are unable to exert sufficient transpulmonary pressure during breathing to clear the liquid from their air spaces. Ususally oxygen therapy is the only specific treatment required to prevent hypoxia.

HYALINE MEMBRANE DISEASE (IDIOPATHIC RESPIRATORY DISTRESS SYNDROME OF THE NEWBORN)

Hyaline membrane disease is probably still the commonest cause of death in infants born in this country (Chamberlain et al, 1975). It affects about 1 per cent of all infants and the incidence increases sharply with decreasing gestation, so that at 27-31 weeks 35-50 per cent of all infants are affected. The illness probably does not occur at term.

The cause of hyaline membrane disease is inadequate production of pulmonary surfactant by type II alveolar pneumonocytes due mainly to immaturity of synthetic mechanisms (Avery and Mead, 1959; Gluck et al, 1972). Asphyxia around the time of birth may worsen the illness by damaging these mechanisms (Reynolds et al, 1965; Gluck et al, 1972). Infants born by Caesarian section before the onset of labour appear to have an increased incidence of the illness (Fedrick and Butler, 1972), possibly because their lungs have not been exposed to the normal increase in plasma cortisol level that occurs at the onset of labour. Whether the infants of diabetic mothers are more likely to develop hyaline membrane disease than other infants remains uncertain, mainly because infants of diabetic mothers seem often to be 
short of breath for reasons other than hyaline membrane disease.

In the absence of sufficient synthesis of pulmonary surfactant the alveoli have an abnormal tendency to collapse during expiration and are difficult to inflate during inspiration. The infant therefore has to exert a large inspiratory pressure with every breath. This inspiratory pressure causes the deep retractions of the chest wall which are the most characteristic physical sign of the illness. Often a grunting noise can be heard coming from the larynx. This grunt is due to the partial closure of the glottis which retards alveolar collapse during expiration. Pulmonary vasoconstriction, with reversion to the fetal type of circulation, is particularly severe in infants with hyaline membrane disease, and is secondary to the combined effects of atelectasis, hypoxia and respiratory acidaemia. In addition to shunting through reopened fetal channels, right-to-left shunts are present through totally atelectatic areas of lung tissue (Murdock et al, 1970). As much as 80 per cent of the cardiac output may be shunted from the venous to the arterial circulation in the most seriously affected infants (Strang and MacLeish, 1961). Without adequate treatment profound hypoxia ensues, with the eventual development of metabolic acidaemia, due to anaerobic glycosis, and death.

The risk of the development of hyaline membrane disease can be predicted in utero by measurement of the lecithin:sphingomyelin ratio in samples of amniotic fluid (Gluck et al, 1971). If the ratio is above 2 , hyaline membrane disease is most unlikely. This test is valuable when a pre-term fetus is at high risk and a balanced judgment has to be reached whether it is safer to deliver the baby or not.

Steroids are capable of stimulating surfactant production by the fetal lung (Avery, 1975). There has, therefore, been much interest in the possibility of preventing hyaline membrane disease by administering steroids to the mother antenatally. Controlled trials suggest that this treatment is effective, particularly if the infant is at $\mathbf{3 2}$ weeks of gestation or less, but the effect is rather small (Liggins and Howie, 1972). If the mother is hypertensive steroids are contraindicated. The exact role of steroid prophylaxis of hyaline membrane disease remains uncertain, and more information is required.

The treatment of established hyaline membrane disease has become very much easier in recent years and mortality rates reported by major centres have fallen from 35 to 50 per cent 10 years ago to less than 10 per cent (Reynolds, 1975) (fig 1). The main reason for this improvement has been the development of effective means for controlling oxygen therapy and preventing hypoxia.

Instead of taking samples of arterial blood inter-

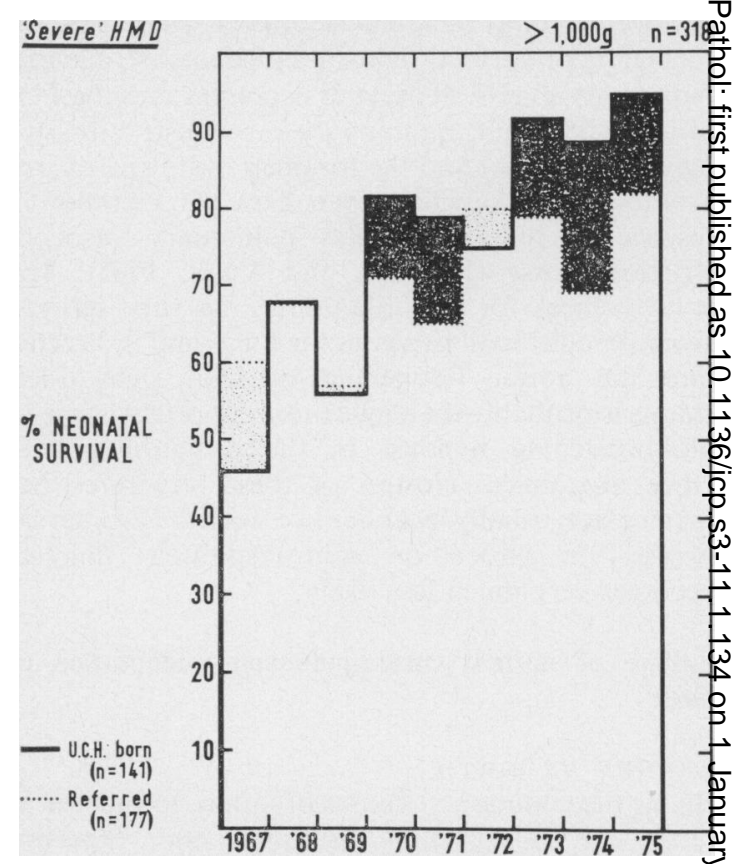

Fig 1 Neonatal survival rate for infants with 'severe' hyaline membrane disease admitted to the Neonatal Unit of University College Hospital in the years 1967-⿱一𫝀㇒ 1975. 'Severe' means that the infants had an arterial oxygen tension $\left(\mathrm{PaO}_{2}\right)$ of less than $90 \mathrm{mmHg}$ while breathing more than 60 per cent oxygen, as well as the usual clinical and radiological features of the illness. One hundred and ninety-four (61 per cent) of the infants $\frac{\mathrm{Q}}{\mathrm{D}}$ needed mechanical ventilation.

mittently for blood gas analysis it is now possible to insert a catheter with a miniaturized oxygen electrode built into its tip into the aorta via the umbilica artery (Conway et al, 1976). Aortic $\mathrm{PaO}_{2}$ is con tinuously displayed and recorded (fig 2 ). The correct inspired oxygen concentration can therefore bo selected with much greater precision than in the pasit. and a course can be steered between the dangers of hypoxia (brain damage and death) on the one han and hyperoxia (retrolental fibroplasia and blindness in preterm infants) on the other. $\mathrm{A} \mathrm{PaO}_{2}$ of $65 \mathrm{~mm}$ $\mathrm{Hg}$ is probably a reasonable level to aim for.

The transcutaneous estimation of $\mathrm{PaO}_{2}$ has als recently been shown to be feasible (Huch et al, 1974) If an oxygen electrode is applied to the skin an\& heated, capillary blood flow increases and trans cutaneous oxygen tension $(\mathrm{tcPO})$ correlates wef with $\mathrm{PaO}_{2}$ under most circumstances. In seriously $\mathrm{i}$ infants with a poor skin blood flow tcPO ${ }_{2}$ undee estimates $\mathrm{PaO}_{2}$ and should not be relied upon. The continuous recording of $\mathrm{PaO}_{2}$ and $t \mathrm{tPO}_{2}$ is extremely valuable in all infants with significant respirator illness. 


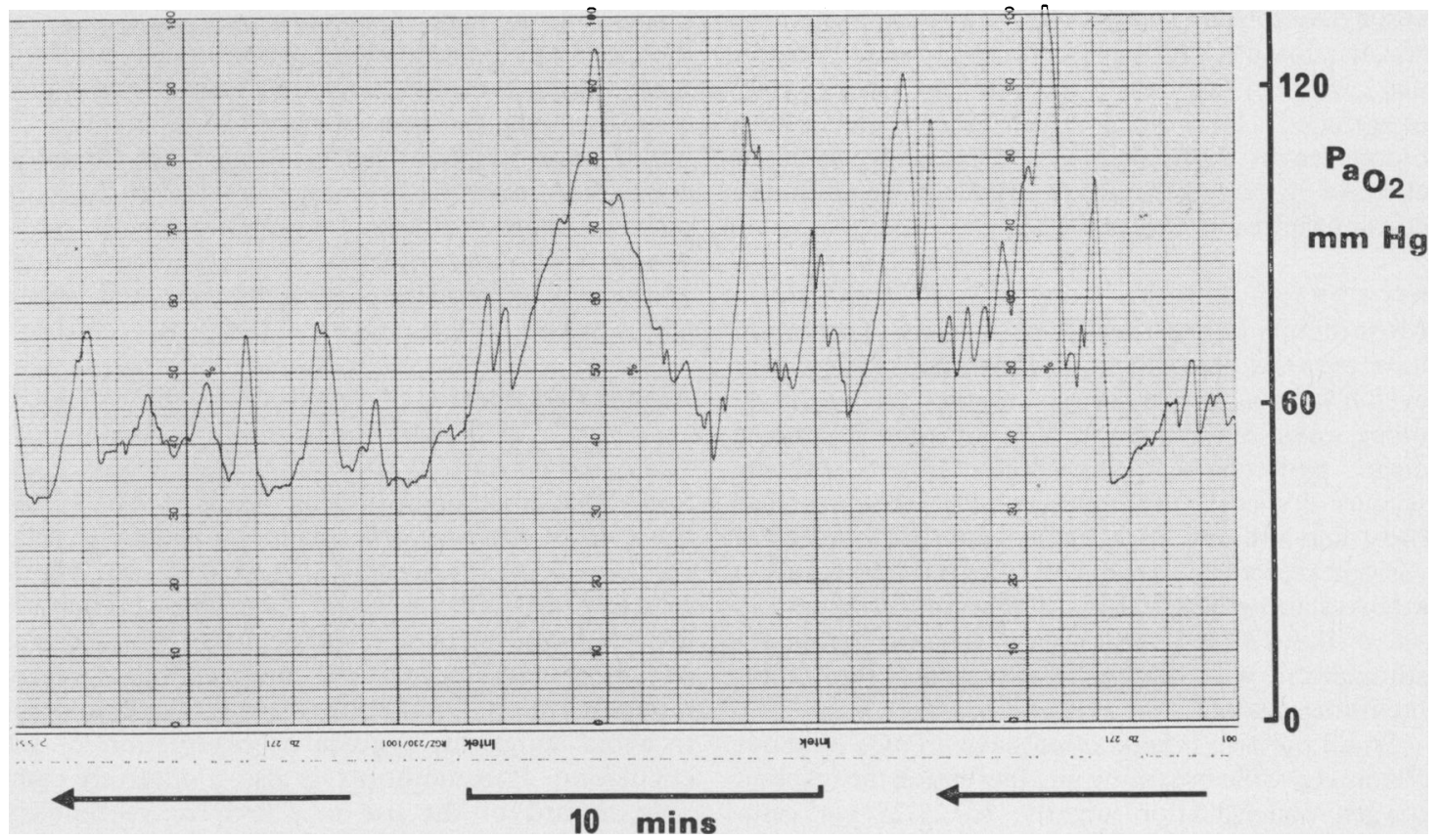

Fig 2 Continuous recording of $\mathrm{PaO}_{2}$, from a 4-day-old, spontaneously breathing infant who was recovering from hyaline membrane disease. She was born at 31 weeks of gestation and weighed $1867 \mathrm{~g}$. She was active but not crying. The inspired oxygen concentration was 50 per cent throughout. $\mathrm{PaO}_{2}$ varied from $45 \mathrm{~mm} \mathrm{Hg}$ to more than $130 \mathrm{mmHg}$ during a 20-minute period.

Infants with hyaline membrane disease, whose $\mathrm{PaO}_{2}$ is falling in spite of an increasing inspired oxygen concentration, can be treated with continuous positive airway pressure (CPAP) (Gregory et al, 1971). The aim is to raise the pressure in the infant's airway so that lung collapse is, partly at least, prevented while spontaneous breathing continues. An adequate indication for initiating CPAP is a $\mathrm{PaO}_{2}$ below $60 \mathrm{mmHg}$ in an infant breathing more than 60 per cent oxygen. $\mathrm{PaO}_{2}$ almost always improves when CPAP is started. Various methods have been employed, including endotracheal tubes, head boxes, face masks, nasal prongs and negative pressure tanks. Possibly the face mask is the method of choice for relatively mildly affected infants (Allen et $a l, 1975$ ) and endotracheal tubes for worse affected ones (Gregory et al, 1971). Pressures of up to about $6 \mathrm{cmH}_{2} \mathrm{O}$ can be applied with the mask, and 10 $\mathrm{cmH}_{2} \mathrm{O}$ with the endotracheal tube.

Infants who do not maintain a satisfactory $\mathrm{PaO}_{2}$ ( $>35-50 \mathrm{mmHg}$ ) when being treated with CPAP or who are tending to become apnoeic need mechanical ventilation. In the past the mortality rate of infants ventilated for hyaline membrane disease was high and many died from bronchopulmonary dysplasia (see page 139). With improved ventilator techniques the outcome has greatly improved (Reynolds, 1974; 1975), and bronchopulmonary dysplasia has become a rarity.

No infant born at a gestational age greater than about 28 weeks should now die or be damaged as a result of hypoxia due to hyaline membrane disease.

\section{PERSISTENT FETAL CIRCULATION OF} UNKNOWN AETIOLOGY

In most pulmonary illnesses hypoxia is due to a combination of interference with gas exchange in the lung with a variable degree of secondary right-to-left shunting through reopened fetal channels. In a small minority of hypoxic infants no pulmonary pathology (or congenital abnormality) can be demonstrated, yet the $\mathrm{PaO}_{2}$ remains low even though the infant is breathing a high concentration of oxygen, indicating right-to-left shunting of blood. Sometimes the preductal $\mathrm{PaO}_{2}$ is much higher than the postductal $\mathrm{PaO}_{2}$, which implies that there is a much larger shunt through the ductus arteriosus than through the foramen ovale. The condition has been called persistent fetal circulation, or persistent transitional circulation. The aetiology is unknown. Possibly some 
vasoactive substance is maintaining pulmonary vasoconstriction after birth. Spontaneous recovery takes place within a few days if the infant is kept properly oxygenated. Tolazoline, which dilates pulmonary blood vessels more than systemic vessels, is often effective in raising the $\mathrm{PaO}_{2}$ and can be given by constant infusion if required.

RECURRENT APNOEA IN PRETERM INFANTS Most infants born at less than 32 weeks of gestation have periodic breathing and short attacks of apnoea even if their lungs are normal and they are well in all other ways. Sometimes, prolonged apnoeic attacks occur, particularly in the smallest infants, causing serious hypoxia. The reason for the irregular breathing and apnoea is inadequate development of various aspects of the control of breathing. Apnoeic attacks can be detected by using monitoring devices set to sound after 10 to $15 \mathrm{sec}$ of apnoea. Peripheral stimulation will almost always start the infant breathing again.

Small preterm infants often have a $\mathrm{PaO}_{2}$ of about $50 \mathrm{mmHg}$ while breathing air. Increasing the inspired oxygen concentration slightly, to 23-25 per cent, raises the $\mathrm{PaO}_{2}$ to about 70 to $80 \mathrm{mmHg}$ and reduces the incidence of apnoea. Increases in inspired oxygen concentration should, however, never be given without measurement of $\mathrm{PaO}_{2}$. The risk of raising the $\mathrm{PaO}_{2}$ to a dangerously high level $(>100$ $\mathrm{mmHg}$ ) is very great in infants with normal lungs, and it is these infants who are most at risk for retrolental fibroplasia. The continuous measurement of $\mathrm{tcPO}_{2}$ may prove to be a valuable aid to therapy.

Other methods of treatment include CPAP and the use of theophylline. Continuous positive airway pressure applied through a face mask (or some other device) at a pressure of $3-4 \mathrm{cmH}_{2} \mathrm{O}$ stimulates stretch receptors in the lung or chest wall and is an effective way of reducing the frequency of apnoea (Kattwinkel et al, 1975). Higher pressures must be avoided, because the lungs are normal and easily become overdistended, with the risk of pneumothorax or obstruction of the circulation. Theophylline is a respiratory stimulant which reduces the incidence of apnoeic attacks (Shannon et al, 1975).

Infants whose breathing fails in spite of the methods described above can usually be mechanically ventilated through a face mask (Allen et al, 1975), thus avoiding the difficulties associated with prolonged intubation in very preterm infants.

\section{Congenital malformations}

By comparison with most other disorders causing hypoxia in newborn infants, congenital mal- formations are rare. The commonest ones affectingo the lungs are diaphragmatic hernia and hypoplastic lungs. Many types of congenital heart disease alsocause hypoxia, because of right-to-left shunting o blood, poor peripheral perfusion, or both. Commoro congenital heart lesions causing serious hypoxiz include tricuspid atresia, transposition of the grea vessels, the hypoplastic left heart syndrome, tota品 anomalous pulmonary venous damage and severø forms of Fallot's tetralogy.

\section{Acquired disorders}

\section{PNEUMOTHORAX}

Spontaneous pneumothoraces, probably due to the large inspiratory efforts made immediately after. delivery, occur in about 1 per cent of all infants (Steele et al, 1971). Usually these pneumothoraces. are small and resolve spontaneously. More serious pneumothoraces occur as a complication of mecoe nium aspiration. Drainage is often required, in order to avoid dangerous hypoxia or obstruction of the circulation. Pneumothorax is also a relatively com mon hazard of the use of CPAP or mechanica馬 ventilation, particularly for the treatment of hyaline membrane disease, with an incidence of about 20 gete cent. Urgent treatment is usually required, but the lung almost always heals within a few days, as ్ㅐㅇㅛ underlying illness resolves.

\section{MECONIUM ASPIRATION}

Intrapartum asphyxia causes gasping and evacuation of the bowel. Hence meconium can be aspirated int the upper airways. Meconium aspiration is particus larly commonly seen in postterm infants, and it is very unusual in infants of less than 37 weeks of̣. gestation. Immediate pharyngeal, and if necessar endotracheal, suction is required at birth, to preven the meconium from being inhaled into the small air $\frac{}{3}$ ways. If large amounts of meconium are inhale deeply into the lung the infant becomes extremelp hypoxic, and is very difficult to treat. Mechanical ventilation is needed and tolazoline has been foun $\$$ to be useful in improving oxygenation. In survivin infants, full recovery takes place within a week.

HAEMORRHAGIC PULMONARY OEDEMA AND MASSIVE PULMONARY HAEMORRHAGE This condition is regarded as a major cause of deat in about 9 per cent of neonatal necropsies (Fedrick and Butler, 1971). It presents clinically as profoun $\$$ collapse, with blood-stained fluid pouring out of th trachea. The fluid is usually a filtrate of plasma, with a small admixture of whole blood (Cole et al, 1973) in other words it is haemorrhagic pulmonar茂 oedema fluid, formed as a result of increased pul $\frac{\widehat{\Phi}}{\bar{\Phi}}$ 
monary capillary pressure. The likely reason for the increase in pressure is that a severe asphyxial episode (of whatever aetiology) causes acute left heart failure, or centralization of the circulation. Any additional factors that tend to raise filtration pressure will increase the risk of haemorrhagic pulmonary oedema, for example hypoproteinaemia, as in severe rhesus haemolytic disease. Disorders of haemostasis are often found and probably result from the underlying asphyxial episode that caused the haemorrhagic oedema. A bleeding tendency encourages continued haemorrhage from ruptured capillaries. Treatment by mechanical ventilation, if undertaken promptly, is often successful, and the outlook for affected infants has improved greatly in the past few years.

By comparison with haemorrhagic pulmonary oedema frank bleeding into the lung is rare and probably occurs only in association with profound haemostatic failure or severe pneumonia.

\section{HYDROPS FETALIS}

Hydrops fetalis is usually due to severe rhesus isoimmunization. Breathing is grossly impaired by oedema of the larynx, lungs and chest wall, together with a reduction of thoracic volume due to the presence of the enlarged liver and spleen and ascites. Unless treated by mechanical ventilation from birth the infants become very severely hypoxic. Many now survive.

\section{PNEUMONIA}

The commonest organism causing severe pneumonia in the immediate newborn period is the group B $\beta$-haemolytic streptococcus acquired before or during delivery from the mother's genital tract. The clinical presentation and radiological appearance sometimes mimic hyaline membrane disease very closely (Ablow et al, 1976). Examination of gastric aspirate for organisms is helpful in making an immediate diagnosis. If any suspicion exists that an infant is infected with the group B streptococcus, or any other organisms, such as $E$. coli, at birth, immediate treatment with antibiotics, before the results of cultures are available, is mandatory. Once unequivocal clinical evidence of infection has developed, the chances of survivial are poor. A suitable combination of antibiotics is penicillin and gentamicin.

\section{CHRONIC LUNG DISEASE}

In 1967, Northway et al gave the first clear description of severe lung fibrosis following mechanical ventilation for hyaline membrane disease. They called the condition 'bronchopulmonary dysplasia' and suggested that it was caused by pulmonary oxygen toxicity. In the same year it was shown that the development of bronchopulmonary dysplasia was not associated with persisting deficiency of pulmonary surfactant (Hawker et al, 1967). The main lesions consist of severe disruption of terminal airways, with fibroblastic proliferation obstructing their lumina and spreading out into the surrounding tissue. The presence of these lesions correlates with the use of very high peak airway pressures (35-60 $\mathrm{cmH}_{2} \mathrm{O}$ ) for more than two days during mechanical ventilation, but not with the inspired oxygen concentration (Taghizadeh and Reynolds, 1976). It has therefore been concluded that the cause of these lesions is mechanical trauma to the lung. If ventilator techniques are used that maintain alveolar inflation without the use of high peak airway pressures bronchopulmonary dysplasia is very rarely seen (Reynolds, 1974; Reynolds and Taghizadeh, 1974). Convincing evidence that pulmonary oxygen toxicity plays any important part in pathogenesis is very hard tofind although it may have a minor role (Taghizadeh and Reynolds, 1976). Surprisingly, the lungs of infants who survive appear to recover completely to normal, although they may take months to do so (Stahlman et al, 1973).

Another cause of chronic lung disease in newborn infants is the 'Wilson-Mikity syndrome' (Wilson and Mikity, 1960). This condition affects greatly preterm infants, who become somewhat hypoxic when they are several days old and have a chest radiological appearance showing streaky shadows due to atelectasis or fibrosis interspersed with areas of compensatory or obstructive emphysema. Before 32 weeks of gestation, infants are unable to protect the upper airway, because they have no adequate cough reflex. In addition, the fine airways are narrow, poorly supported with cartilage (Burnard et al, 1965), and easily become obstructed. Probably the Wilson-Mikity syndrome is not a clinical entity but results from any disorder that causes widespread uneven obstruction of airways in greatly preterm infants. For example, aspiration of feed, or retained pulmonary secretions in infants ventilated through endotracheal tubes, can both produce radiological appearance identical to that originally described. After a protracted course, most affected infants recover.

\section{Consequences of severe hypoxia}

Lack of oxygen causes anaerobic glycolysis, with the development of a metabolic acidosis due to accumulation of lactic acid. The combination of hypoxia and acidosis impairs cardiac function (Downing et al, 1965) and increases pulmonary vascular resistance (Rudolph and Yuan, 1966). In addition, severe hypoxia causes interference with the production of clotting factors from the liver and may also initiate 
disseminated intravascular coagulation. A tendency to bleed is common in any severely hypoxic infant (Chessells and Wigglesworth, 1972).

There is a strong association between hypoxia and intraventricular haemorrhage-a very common cause of death in preterm infants. The mechanism of intraventricular haemorrhage is probably that an asphyxial episode produces an increase in intravascular pressure which ruptures vulnerable vessels in the germinal matrix (Cole et al, 1974; Hambleton and Wigglesworth, 1976). Hypoxia is also a major factor in the pathogenesis of necrotizing entercolitis (Santulli et al, 1975). This illness often follows severe asphyxia at birth, or interference with blood flow to or from the gut by the use of umbilical arterial or venous catheters (Bunton et al, 1977). The pathological results of hypoxia, including its effect on the brain, are dealt with elsewhere in this symposium.

\section{Conclusion}

Hypoxia in newborn infants is becoming much easier to prevent, detect and treat. Nevertheless the successful management of potentially hypoxic fetuses and newborn infants remains the major challenge to all physicians concerned with perinatal care. What is at stake is not only that sick infants should survive, but equally or more importantly that the survivors should be normal children. Recent follow-up studies show that this aim can, with few exceptions, now be achieved (Stewart and Reynolds, 1974; Davies and Stewart, 1975; Durbin et al, 1976).

\section{References}

Ablow, R. C., Driscoll, S. G., Effmann, E. L., Gross, I., Jolles, C. J., Uauy, R., and Warshaw, J. B. (1976). A comparison of early-onset Group B streptococcal neonatal infection and the respiratory-distress syndrome of the newborn. New England Journal of Medicine, 294, 65-70.

Adamson, T. M., Boyd, R. D. H., Platt, H. S., and Strang, L. B. (1969). Composition of alveolar liquid in the foetal lamb. Journal of Physiology, 204, 159-168.

Ahlfeld, F. (1888). Ueber bisher noch nicht beschriebene intrauterine Bewegungen des Kindes. Verhandlungender Deutschen Gesellschaft für Gynäkologie, 2, 203-206.

Allen, L. P., Blake, A. M., Durbin, G. M., Ingram, D., and Reynolds, E. O. R. (1975). Continuous positive airway pressure and mechanical ventilation by facemask in newborn infants. British Medical Journal, 4, 137-139.

Avery, M. E. (1975). Pharmacological approaches to the acceleration of fetal lung maturation. British Medical Bulletin, 31, 13-17.

Avery, M. E., Gatwood, O. B., and Brumley, G. (1966). Transient tachypnea of newborn. American Journal of Diseases of Children, 111, 380-385.

Avery, M. E., and Mead, J. (1959). Surface properties in relation to atelectasis and hyaline membrane disease. American Journal of Diseases of Children, 97, 517-523.

Boddy, K., and Dawes, G. S. (1975). Fetal breathing. British Medical Bulletin, 31, 3-7.
Bunton, G. L., Durbin, G. M., McIntosh, N., Shaw, D. G., Taghizadeh, A., Reynolds, E. O. R., Rivers, R. P. A., and Urman, G. (1977). Necrotizing enterocolitis: controlled으 study of three years' experience in a neonatal intensive care unit. Archives of Disease in Childhood, in press.

Burnard, E. D., Grattan-Smith, P., Picton-Warlow, G. G., and Grauaug, A. (1965). Pulmonary insufficiency in prematurity. Australian Paediatric Journal, 1, 12-38.

Cassin, S., Dawes, G. S., Mott, J. C., Ross, B. B., and $\frac{\overline{\bar{C}}}{}$ Strang, L. B. (1964). The vascular resistance of the foetal $\mathbb{D}$ and newly ventilated lung of the lamb. Journal of Physiology, 171, 61-79.

Chamberlain, R., Chamberlain, G., Howlett, B., and Claireaux, A. (1975). British Births 1970: Vol I, First Week. of Life. Heinemann, London.

Chessels, J. M., and Wigglesworth, J. S. (1972). Coagulation studies in preterm infants with respiratory distress and intracranial haemorrhage. Archives of Disease in Childhood, 음 47, 564-570.

Cole, V. A., Durbin, G. M., Olaffson, A., Reynolds, E. O. R., Rivers, R. P. A., and Smith, J. F. (1974). Pathogenesis of intraventricular haemorrhage in newborn infants. Archives of Disease in Childhood, 49, 722-728.

Cole, V. A., Normand, I. C. S., Reynolds, E. O. R., and $\vec{\omega}$ Rivers, R. P. A. (1973). Pathogenesis of hemorrhagico pulmonary edema and massive pulmonary hemorrhage in the newborn. Pediatrics, 51, 175-187.

Conway, M., Durbin, G. M., Ingram, D., McIntosh, N., č Parker, D., Reynolds, E. O. R., and Soutter, L. P. (1976). Continuous monitoring of arterial oxygen tension using a catheter-tip polarographic electrode in infants. Pediatrics,, 57, 244-250.

Cook, C. D., Drinker, P. A., Jacobson, H. N., Levison, 19 and Strang, L. B. (1963). Control of pulmonary blood flow. in the foetal and newly born lamb. Journal of Physiologe $169,10-29$.

Davies, P. A., and Stewart, A. L. (1975). Low-birth-weight infants: neurological sequelae and later intelligence. British Medical Bulletin, 31, 85-91.

Dawes, G. S. (1968). Foetal and Neonatal Physiology, pp. 91-ब 105. Year Book Medical Publishers, Chicago.

Downing, S. E., Talner, N. S., and Gardner, T. H. (1965). $\overline{\bar{O}}$ Ventricular function in the newborn lamb. American 3 Journal of Physiology, 208, 931-937.

Durbin, G. M., Rawlings, G., Reynolds, E. O. R., Stewart, A. L., and Turcan, D. M. (1976). Follow-up of infants at high risk of mental and physical handicap. Programme and Abstracts, European Society for Paediatric Research, Rotterdam, June 21-24.

Egan, E. A., Olver, R. E., and Strang, L. B. (1975). Changes. in non-electrolyte permeability of alveoli and the absorptiono of lung liquid at the start of breathing in the lamb. Journal of Physiology, 244, 161-179.

Fedrick, J., and Butler, N. R. (1971). Certain causes of neo-글 natal death: IV. Massive pulmonary haemorrhage. Biology of the Neonate, 18, 243-262.

Fedrick, J., and Butler, N. R. (1972). Hyaline-membrane disease. (Letter). Lancet, 2, 768-769.

Gluck, L., Kulovich, M. V., Borer, R. C. Jr., Brenner, P. H., N Anderson, G. G., and Spellacy, W. N. (1971). Diagnosis of N the respiratory distress syndrome by amniocentesis. $\omega$ American Journal of Obsterrics and Gynecology, 109, 440-ס 445.

Gluck, L., Kulovich, M. V., Eidelman, A. I., Cordero, L., 트 and Khazin, A. F. (1972). Biochemical development of surface activity in mammalian lung. IV. Pulmonary: lecithin synthesis in the human fetus and newborn and $\square$ etiology of the respiratory distress syndrome. Pediatric Research, 6, 81-99.

Gregory, G. A., Kitterman, J. A., Phibbs, R. H., Tooley, 
W. H., and Hamilton, W. K. (1971). Treatment of the idiopathic respiratory-distress syndrome with continuous positive airway pressure. New England Journal of Medicine, 284, 1333-1340.

Hambleton, G., and Wigglesworth, J. S. (1976). Origin of intraventricular haemorrhage in the preterm infant. Archives of Disease in Childhood, 51, 651-659.

Hawker, J. M., Reynolds, E. O. R., and Taghizadeh, A. (1967). Pulmonary surface tension and pathological changes in infants dying after respirator treatment for severe hyaline membrane disease. Lancet, 2, 75-77.

Huch, R., Lübbers, D. W., and Huch, A. (1974). Reliability of transcutaneous monitoring of arterial $\mathrm{PO}_{2}$ in newborn infants. Archives of Disease in Childhood, 49, 213-218.

Humphreys, P. W., Normand, I. C. S., Reynolds, E. O. R., and Strang, L. B. (1967). Pulmonary lymph flow and the uptake of liquid from the lungs of the lamb at the start of breathing. Journal of Physiology, 193, 1-29.

Johnson, P., Robinson, J. S., and Salisbury, D. (1973). The onset and control of breathing after birth. In Foetal and Neonatal Physiology (Sir Joseph Barcroft Centenary Symposium, 1972), edited by R. S. Comline, K. W. Cross, G. S. Dawes, and P. W. Nathanielsz. pp. 217-221. Cambridge University Press, London.

Karlberg, P., Cherry, R. B., Escardó, F. E., and Köch, G. (1962). Respiratory studies in newborn infants. II. Pulmonary ventilation and the mechanics of breathing in the first minutes of life, including the onset of respiration. Acta Paediatrica, 51, 121-136.

Kattwinkel, J., Nearman, H. S., Fanaroff, A. A., Katona, P. G., and Klaus, M. H. (1975). Apnea of prematurity. Comparative therapeutic effects of cutaneous stimulation and nasal continuous positive airway pressure. Journal of Pediatrics, 86, 588-592.

Kovalčik, V. (1963). The response of the isolated ductus arteriosus to oxygen and anoxia. Journal of Physiology, 169, 185-197.

Liggins, G. C., and Howie, R. N. (1972). A controlled trial of antepartum glucocorticoid treatment for prevention of the respiratory distress syndrome in premature infants. Pediatrics, 50, 515-525.

Murdock, A. I., Kidd, B. S. L., Llewllyn, M. A., Reid, M. M., and Swyer, P. R. (1970). Intrapulmonary venous admixture in the respiratory distress syndrome. Biology of the Neonate, 15, 1-7.

Normand, I. C. S., Olver, R. E., Reynolds, E. O. R., and Strang, L. B. (1971). Permeability of lung capillaries and alveoli to non-electrolytes in the foetal lamb. Journal of Physiology, 219, 303-330.

Northway, W. H. Jr., Rosan, R. C., and Porter, D. Y. (1967). Pulmonary disease following respirator therapy of hyalinemembrane disease. New England Journal of Medicine, 267, 357-368.

Olver, R. E., Reynolds, E. O. R., and Strang, L. B. (1973). Foetal lung liquid. In Foetal and Neonatal Physiology (Sir Joseph Barcroft Centenary Symposium, 1972), edited by R. S. Comline, K. W. Cross, G. S. Dawes and P. W.
Nathanielsz, pp. 186-207. Cambridge University Press, London.

Purves, M. J., and Biscoe, T. J. (1966). Development of chemoreceptor activity. British Medical Bulletin, 22, 5660.

Reynolds, E. O. R. (1974). Pressure waveform and ventilator settings for mechanical ventilation in severe hyaline membrane disease. International Anesthesiology Clinics, 12, 259-280.

Reynolds, E. O. R. (1975). Management of hyaline membrane disease. British Medical Bulletin, 31, 18-24.

Reynolds, E. O. R., Jacobson, H. N., Motoyama, E. K. Kikkawa, Y., Craig, J. M., Orzalesi, M. M., and Cook, C. D. (1965). The effect of immaturity and prenatal asphyxia on the lungs and pulmonary function of newborn lambs: the experimental production of respiratory distress. Pediatrics, 35, 382-392.

Reynolds, E. O. R., and Taghizadeh, A. (1974). Improved prognosis of infants mechanically ventilated for hyaline membrane disease. Archives of Disease in Childhood, 49, 49, 505-515.

Rudolph, A. M., and Yuan, S. (1966). Response of the pulmonary vasculature to hypoxia and $\mathrm{H}^{+}$ion concentration changes. Journal of Clinical Investigation, 45, 399. 411.

Santulli, T. V., Schullinger, J. N., Heird, W. C., Gongaware, R. D., Wigger, J., Barlow, B., Blanc, W. A., and Berdon, W. E. (1975). Acute necrotizing enterocolitis in infancy: a review of 64 cases. Pediatrics, 55, 376-387.

Shannon, D. C., Gotay, F., Stein, I. M., Rogers, M. C., Todres, I. D., and Moylan, F. M. B. (1975). Prevention of apnea and bradycardia in low-birthweight infants. Pediatrics, 55, 589-594.

Simmons, M. A., Adcock, E. W., Bard, H., and Battaglia, F. C. (1974). Hypernatramia and intracranial haemorrhage in neonates. New England Journal of Medicine, 291, 6-10.

Stahlman, M., Hedvall, G., Dolanski, E., Faxelius, G., Burko, H., and Kirk, V. (1973). A six-year follow-up of clinical hyaline membrane disease. Pediatric Clinics of North America, 20, 433-446.

Steele, R. W., Metz, J. R., Bass, J. W., and Dubois, J. J. (1971). Pneumothorax and pneumomediastinum in the newborn. Radiology, 98, 629-632.

Stewart, A. L., and Reynolds, E. O. R. (1974). Improved prognosis for infants of very low birth weight. Pediatrics, 54, 724-735.

Strang, L. B., and MacLeish, M. H. (1961). Ventilatory failure and right-to-left shunt in newborn infants with respiratory distress. Pediatrics, 28, 17-27.

Taghizadeh, A., and Reynolds, E. O. R. (1976). Pathogenesis of bronchopulmonary dysplasia following hyaline membrane disease. American Journal of Pathology, 82, 241-264.

Wilson, M. G., and Mikity, V. G. (1960). A new form of respiratory disease in premature infants. American Journal of Diseases of Children, 99, 489-499. 